\title{
Bibliography
}

\section{Archival material}

\begin{tabular}{|c|c|}
\hline UT & $\begin{array}{l}\text { Association of University Teachers Archive, Modern Records } \\
\text { Centre, University of Warwick }\end{array}$ \\
\hline ISS Baldwin & Earl Baldwin of Bewdley, Papers, Cambridge University Libran \\
\hline & rd Cecil of Chelwood, Papers, British Library, London \\
\hline & Dame Kathleen Courtney, Papers, Women's Library, London \\
\hline avidson Papers & Archbishop Davidson, Papers, Lambeth Palace Library, London \\
\hline & $\begin{array}{l}\text { Willoughby Hyett Dickinson, Papers, London Metropolitan } \\
\text { Archives }\end{array}$ \\
\hline ang & Archbishop Lang, Papers, Lambeth Palace Library, London \\
\hline $\mathrm{CP}$ & ambeth Conference Papers, La \\
\hline NU & $\begin{array}{l}\text { League of Nations Union Archive, British Library of Political } \\
\text { and Economic Science, London }\end{array}$ \\
\hline LPA & $\begin{array}{l}\text { Labour Party Archive, Labour History Archive and Study } \\
\text { Centre, Manchester }\end{array}$ \\
\hline ICA & Margery Corbett Ashby, Papers, Women's Library, London \\
\hline $\mathrm{IOH}$ & ussex LiDr \\
\hline ISS & Iurray Papers, Bodleian Library, Oxford \\
\hline NBK & $\begin{array}{l}\text { Philip Noel Baker Papers, Churchill Archives Centre, } \\
\text { Cambridge }\end{array}$ \\
\hline $\mathrm{NCW}$ & $\begin{array}{l}\text { National Council of Women Archive, London Metropolitan } \\
\text { Archives }\end{array}$ \\
\hline NFWI & $\begin{array}{l}\text { National Federation of Women's Institutes Archive, The } \\
\text { Women's Library, London }\end{array}$ \\
\hline NPC & $\begin{array}{l}\text { National Peace Council Archive, British Library of Political and } \\
\text { Economic Science, London }\end{array}$ \\
\hline TNA & $\begin{array}{l}\text { The National Archives: CAB 21/411, ED 12/216, ED 121/144, } \\
\text { PC 12/34, PRO 30/69/183, WO 32/5941, LAB 2/1007/ } \\
\text { IL133/1930, FO 954/14B, FO 371/22562, FO 371/2443, FO } \\
\text { 366/928, PREM 1/178 }\end{array}$ \\
\hline $\mathrm{UC}$ & $\begin{array}{l}\text { Trades Union Congress Archive, Modern Records Centre, } \\
\text { University of Warwick }\end{array}$ \\
\hline
\end{tabular}


$\mathrm{WNC}$

League of Nations Union, Welsh National Council Archive, National Library of Wales, Aberystwyth

MSS Zimmern Sir Alfred Zimmern, Papers, Bodleian Library, Oxford

\section{LNU branch records}

$\begin{array}{ll}\text { BA } & \text { Bury: Bury Archives, Bury } \\ \text { BPL } & \text { Beckenham: Bromley Public Library, Bromley } \\ \text { BRO } & \text { Henleaze and Westbury, and Redland: Bristol Record Office, } \\ & \text { Bristol } \\ \text { CRO } & \text { Wadebridge: Cornwall Record Office, Truro } \\ \text { DCRO } & \text { Darlington: Durham County Record Office, Durham } \\ \text { ELHC } & \text { Ealing and District: Ealing Local History Centre, Ealing } \\ \text { ESRC } & \text { Eastbourne: East Sussex Record Office, Lewes } \\ \text { ESRO } & \text { Brighton and Hove: East Sussex Record Office, Lewes } \\ \text { MAC } & \text { Northwood: Modern Archives Centre, University of Warwick } \\ \text { MALS } & \text { Withington: Manchester Archives \& Local Studies, } \\ & \text { Manchester } \\ \text { ROL } & \text { Leicester: Record Office for Leicestershire, Leicester } \\ \text { SHC } & \text { Oxted and Limpsfield: Surrey History Centre, } \\ & \text { Kingston-upon-Thames } \\ \text { SROB } & \text { Sudbury: Suffolk Record Office, Bury St Edmunds } \\ \text { SROL } & \text { Lowestoft: Suffolk Record Office, Lowestoft } \\ \text { WL } & \text { Warrington: Warrington Library, Warrington } \\ \text { WSHC } & \text { Mere: Wiltshire and Swindon History Centre, Chippenham } \\ \text { WYASH } & \text { Halifax: West Yorkshire Archive Service, Halifax } \\ \text { WYASW } & \text { Wakefield: West Yorkshire Archive Service, Wakefield }\end{array}$

\section{Other}

Archives of the London County Council, London Metropolitan Archives

Bury Peace Week Scrapbook: Bury Archives, Bury

Darlington Labour Party: Durham County Record Office, Durham

Ealing and District Conservative Association: London Metropolitan Archives, London

Leicester Rotary Club: Record Office for Leicestershire, Leicester

Records kept by the first Director of Education to Bedfordshire Local Education Authority, Bedfordshire and Luton Archives

Winchester Unionist and Conservative Association, Hampshire Record Office,

Winchester

\section{Interview material}

Interview with Phillip Noel-Baker, 8SUF/B/150, in Oral Evidence on the Suffragette and Suffragist Movements, Women's Library, London 


\section{Digital resources}

Oxford Dictionary of National Biography (online version)

1911 Census Online

The Times Digital Archive

\section{Newspapers and periodicals}

Abyssinia

The Advocate

The Beckenham and Penge Advertiser

Bolton Evening Nerws

Brighton Gazette

The British Legion Journal

The British Soroptimist

The British Weekly

Bury Times

Church \& World

Church Times

Contemporary Review

The Covenant

Daily Express

Daily Herald

Daily Mirror

Darlington and Stockton Times

Eastbourne Gazette

Foreign Affairs

The Free Church Chronicle

Hansard Parliamentary Debates

Headway

Headway in Wartime

The Highway

History

Home and Country

International Outlook

IPC Monthly Bulletin

IPC News Letter

Keighley News and Bingley Chronicle

The Kent Quarterly

Labour Organiser

Lancashire Daily Post

The League

The League of Nations Educational Survey

The League of Nations Journal

League of Nations Society Monthly Report 


\author{
League News \\ The Leicester Mercury \\ The Listener \\ The London Bulletin \\ Manchester Guardian \\ Middlesex County Times \\ The Nation \\ Nelson Leader \\ The New Era \\ The New Outlook \\ The New Ploughshare \\ New Statesman and Nation \\ Northern Echo \\ Political Quarterly \\ Public Opinion Quarterly \\ Rotary Wheel \\ Round Table \\ The Scouter \\ Stockton and Darlington Times \\ Teacher's World \\ The UDC \\ United Nations Nerws \\ The Weekly IPC Nerws \\ Woman's Leader
}

\title{
Directories/reference works
}

The Ealing Year Book and Who's Who

Kelly's Directory of Brighton, Hove, Preston and Neighbourhood

Kelly's Directory of Cornwall

Kelly's Directory of the Counties of Cambridge, Norfolk and Suffolk

Kelly's Directory of Durham and Northumberland

Kelly's Directory of Lancashire

Kelly's Directory of Lowestoft, Beccles and Neighbourhood

Kelly's Directory of the West Riding of Yorkshire

Kelly's Directory of Wiltshire

Manchester Grammar School: A Biographical Register of Old Mancunians, 1888-1951

\section{Other published primary sources}

Adams, Mary (ed.), The Modern State, by Leonard Woolf, Lord Eustace Percy, Mrs Sidney Webb, Professor WGS Adams, Sir Arthur Salter (London, 1933)

Amery, LS, My Political Life, Vol.3: The Unforgiving Years, 1929-1940 (London, 1955)

Angell, Norman, The Great Illusion (London, 1910)

The Press and the Organisation of Society (London, 1922) 
_IfWe Disarm Does it Mean More Unemployment? (London, 1931)

- After All (London, 1951)

Bailey, SH, International Studies in Great Britain (London, 1933)

- International Studies in Modern Education (Oxford, 1938)

Beveridge, William, Peace by Federations (London, 1940)

Brewer Boeckel, Florence, 'Women in International Affairs', Annals of the American Academy of Political and Social Science, 143 (May 1929), 230-248

Brittain, Vera, Women's Work in Modern England (London, 1928)

Carr, EH, 'Public Opinion as a Safeguard of Peace', International Affairs, 15 (1936), 846-862.

The Twenty Years' Crisis, 1919-1939: An Introduction to the Study of International Relations (Basingstoke, 2001, first published 1939)

Cecil, Viscount, 'International Democracy', Political Quarterly, 5 (1934), 323-341

_ 'The League of Nations Union and Gilbert Murray', in (no editor), Essays in Honour of Gilbert Murray (London, 1936)

- A Great Experiment: An Autobiography (London, 1941) All The Way (London, 1949)

Churchill, Winston, The Second World War, Vol.I: The Gathering Storm (London, 1948)

Cole, GDH, The People's Front (London, 1937)

The Council for the Study of International Relations: Its Aims, Methods and Organisation (London, n.d.)

Dalton, Hugh, Towards the Peace of Nations: A Study in International Politics (London, 1928)

The Fateful Years: Memoirs 1931-1945 (London, 1957)

Davies, Gwilym, Intellectual Co-operation between the Two World Wars (London, 1944)

Drummond, H Ann, History in Schools: A Study of Some of its Problems (London, 1929)

Eden, Anthony, Facing the Dictators: The Memoirs of Anthony Eden, Earl of Avon (London, 1962)

Education and the League of Nations: Report of the Joint Committee of Enquiry into the

Teaching of the Aims and Achievements of the League of Nations (London, 1929)

Eppstein, John, Ten Years' Life of the League of Nations: A History of the Origins of the League and of its Development from AD 1919 to 1929 (London, 1929)

- Must War Come? The International Situation Reviewed in the Light of Papal

Teaching and Action Concerning Peace and War in Modern Times (London, 1935)

- A Catholic Looks at the League (Oxford, 1937)

Essays in Honour of Gilbert Murray (London, 1936)

The Form and Function of the World Organisation proposed by the London International Assembly (London, n.d.)

Gibbs, Philip, England Speaks (London, 1935)

Gooch, GP, The Unity of Civilization (London, 1933)

- Citizenship and History (London, 1936)

Gore, Charles, The League of Nations: The Opportunity of the Church (London, 1918)

Gould, FJ, The League of Nations Spirit in the Schools (London, 1927)

Hankey, Maurice, Diplomacy by Conference: Studies in Public Affairs 1920-1946 (London, 1946) 
Henson, Hensley, Abyssinia (London, 1936)

Hobson, JA, A League of Nations (London, 1915)

Keeton, George, "International Relations" in Adult Education Classes', Adult Education, 7:1 (September 1934), 25-33.

Kerr, Philip, The Outlawry of War (London, 1929)

Laski, Harold, Democracy in Crisis (London, 1933)

Livingstone, Adelaide, The Peace Ballot: The Official History (London, 1935)

Madge, Charles and Harrisson, Tom, Britain by Mass Observation (Harsondsworth, 1939)

McCallum, RB, Public Opinion and the Last Peace (London, 1944)

Marshall, Catherine, 'Women and War', in Margaret Kamester and Jo Vellacott (eds), Militarism Versus Feminism: Writings on Women and War (London, 1987)

Marvin, FS (ed.), England and the World (London, 1925)

- The Evolution of World-Peace (London, 1933)

Mass-Observation, The Pub and the People: A Worktown Study (London, 1943)

_- Peace and the Public: A Study by Mass Observation (London, 1947)

Milne, AA, 'Five Minutes of Your Time' (London, 1937)

Morel, ED, Ten Years of Secret Diplomacy: An Unheeded Warning (London, 1915)

Murray, Gilbert, 'The Herd Instinct and the War', in (no editor), The International

Crisis in its Ethical and Psychological Aspects (London, 1915), 22-45

- The League of Nations and the Democratic Idea (London, 1918)

The Future of the British Empire in Relation to the League of Nations (Sheffield, 1928)

The Ordeal of this Generation: The War, the League and the Future (London, 1929)

Then and Now: The Changes of the Last Fifty Years (Oxford, 1935)

Liberality and Civilization (London, 1938)

The League of Nations Movement: Some Recollections of the Early Days (London, 1955)

Nicolson, Harold, 'Modern Diplomacy and British Public Opinion', International Affairs, 14:5 (1935), 599-618

—_British Public Opinion and Foreign Policy', Public Opinion Quarterly, 1:1 (1937), 53-63

—Diplomacy (London, 1963, 3rd ed. First published 1939)

Noel Baker, PJ, 'The People's Part in Disarmament', The Listener, 16 December 1931, 1031-1033

Northcroft, DM, Women at Work in the League of Nations (London, 1923)

Orwell, George, Essays (London, 2000, first published 1939)

Ponsonby, Arthur, Parliament and Foreign Policy (London, 1915, first published 1914)

— The Control of Foreign Policy (London, 1918, revised ed. of above pamphlet)

Potter, Pitman, 'League Publicity: Cause or Effect of League Failure?', Public Opinion Quarterly, 2:3 (1938), 399-412

Power, Eileen (ed.), A Bibliography for Teachers of History (London, 1919)

Prescott, DA, Education and International Relations: A Study of the Social Forces That

Determine the Influence of Education (Cambridge, MA, 1930)

Priestley, JB, English Journey (London, 1934) 
The Proceedings of COPEC: Being a Report of the Meetings of the Conference on Christian Politics, Economics and Citizenship (London, 1924)

Rathbone, Eleanor, War Can Be Averted (London, 1938)

Report of the Royal Commission on Justices of the Peace, 1946-1948 (HMSO: Cmd 7463, 1948)

Roper Power, ER, 'The Social Structure of an English County Town', Sociological Review, 29 (1937), 391-413

Salter, Arthur, 'The Technique of Open Diplomacy', Political Quarterly, 3 (1932), 58-70

Sanders, Captain WM Stephen, Disarmament and the Displaced Worker (London, 1932)

Self, Robert CG (ed.), The Austen Chamberlain Diary Letters: The Correspondence of Sir Austen Chamberlain with his Sisters Hilda and Ida (Cambridge, 1995)

Seton-Watson, RW, 'A Plea for the Study of Contemporary History', History, 14 (1929), 1-18

Seton-Watson, RW, Wilson, J Dover, Zimmern, Alfred E and Greenwood, Arthur, The War and Democracy (London, 1914)

Shropshire, Olive, The Teaching of History in English Schools (New York, 1936)

Smith, Jean and Toynbee, Arnold (eds), Gilbert Murray: An Unfinished Autobiography (London, 1960)

Smuts, JC, The League of Nations: A Practical Suggestion (London, 1918)

- General Smuts and the League (London, 1923)

- The Disarmed Peace (London, 1932)

— Two Statements: The Peace Treaty (London, n.d.)

Woodrow Wilson's Place in History (London, n.d.)

Spaull, Hebe, Women Peace-Makers (London, 1924)

Spender, JA, The Public Life, Vol.II (London, 1925)

Stewart, Michael, Bias and Education for Democracy (Oxford, 1938)

Strachey, Ray, Careers and Openings for Women: A Survey of Women's Employment and a Guide for those Seeking Work (London, 1935)

Swanwick, Helena, Women and War (London, 1915)

- I Have Been Young (London, 1935)

Templewood, Viscount, Nine Troubled Years (London, 1954)

Thomas, FG, The Changing Village: An Essay on Rural Reconstruction (London, 1939)

Toynbee, Arnold, The League in the East (London, 1920)

The Conduct of British Empire Foreign Relations since the Peace Settlement (London, 1928)

Unstead, JF, Europe of Today (London, 1921)

- The British Isles of Today (London, 1922)

World Geography and World Problems (London, 1923)

Wallas, Graham, Human Nature in Politics (London, 1908)

Webster, CK, 'The Study of International History', History, 18 (1933), 97-114

Wells, HG, Experiment in Autobiography (London, Vol.2, 1934)

White, Freda, Mandates (London, 1926)

Whitehouse, JH and Gooch, GP, Wider Aspects of Education (London, 1924) 
Williams, Aneurin, 'Proposals for a League of Peace and Mutual Protection Among

Nations', Contemporary Review, November 1914, 628-636

Woolf, Leonard, International Government: Two Reports (London, 1916)

Mandates and Empire (1920)

- Imperialism and Civilization (London, 1928)

Young, George, Diplomacy Old and New (London, 1921)

Zimmern, Alfred, The Third British Empire (London, 1926)

_ Public Opinion and International Affairs (Manchester, 1931)

The Economic Causes of War (London, 1934)

\section{Published secondary material}

Adams, Michael, Voluntary Service Overseas: The Story of the First Ten Years (London, 1968)

Alberti, Johanna, Beyond Suffrage: Feminists in War and Peace, 1914-1928 (Basingstoke, 1989)

Andrews, Maggie, The Acceptable Face of Feminism: The Women's Institute as a Social Movement (London, 1997)

Barr, Niall, The Lion and the Poppy: British Veterans, Politics, and Society, 1921-1939 (London, 2005)

Barton, Susan, Working-Class Organisations and Popular Tourism, 1840-1970 (Manchester, 2005)

Beaumont, Caitriona, 'The Women's Movement, Politics and Citizenship 19181950s', in Ina Zweiniger-Bargielowska (ed.), Women in Twentieth-Century Britain (Harlow, 2001), 262-277

Bebbington, DW, The Nonconformist Conscience: Chapel and Politics, 1870-1914 (London, 1982)

Beer, Samuel H, Modern British Politics: Parties and Pressure Groups in the Collectivist Age (London, 1965)

Beers, Laura, 'Whose Opinion? Changing Attitudes Towards Opinion Polling in British Politics, 1937-1964', Twentieth Century British History, 17:2 (2006), 177-205

Bentley, Michael, The Liberal Mind, 1914-1929 (Cambridge, 1977)

— 'Liberal Politics and the Grey Conspiracy of 1921', Historical Journal, 20 (1977), 461-478

Berg, Maxine, A Woman in History: Eileen Power, 1889-1940 (Cambridge, 1996)

Berry, Paul and Bishop, Alan (eds), Testament of a Generation: The Journalism of Vera Brittain and Winifred Holtby (London, 1985)

Bingham, Adrian, 'An Era of Domesticity? Histories of Women and Gender in Interwar Britain', Cultural and Social History, 1 (2004), 225-233

- Gender, Modernity, and the Popular Press in Inter-war Britain (Oxford, 2004)

Birebent, Christian, Militants de la Paix et de la SDN (Paris, 2007)

Birn, Donald S, 'The League of Nations Union and Collective Security', Journal of Contemporary History 9 (1974), 131-159

The League of Nations Union 1918-1945 (Oxford, 1981) 
Blaazer, David, The Popular Front and the Progressive Tradition: Socialists, Liberals, and the Quest for Unity, 1884-1939 (Cambridge, 1992)

Black, Lawrence, The Political Culture of the Left in Affluent Britain, 1951-64: Old Labour, New Britain? (Basingstoke, 2003)

- 'The Lost World of Young Conservatism', Historical Journal, 51:4 (2008), 991-1024

Bosco, Andrea and Navari, Cornelia (eds), Chatham House and British Foreign Policy 1919-1945: The Royal Institute of International Affairs during the Interwar Period (London, 1994)

Bottomore, Thomas, 'Social Stratification in Voluntary Organisation', in DV Glass (ed.), Social Mobility in Britain (London, 1954)

Bracco, Rosa Maria, Merchants of Hope: British Middlebrow Writers and the First World War, 1919-1939 (Oxford, 1993)

Bramsted, Ernest, 'Apostles of Collective Security: The LNU and its Functions', Australian Journal of Politics and History, 13 (1967), 347-364

Brasnett, Margaret, Voluntary Social Action: A History of the National Council of Social Service, 1919-1969 (London, 1969)

Brehony, Kevin J, 'A New Education for a New Era: The Contribution of the Conferences of the New Education Fellowship to the Disciplinary Field of Education, 1921-1938', Paedagogica Historica, 40:5\&6 (October 2004), 733755

Brown, Callum, Religion and Society in Twentieth-Century Britain (Harlow, 2006)

Buchanan, Tom, Britain and the Spanish Civil War (Cambridge, 1997)

Burkman, Thomas, 'The Paradox of Pacifism and Powerhood in the Japanese League of Nations Movement', Peace and Change, 6:1-2 (1980), 43-48

Butler, DE, The Electoral System in Britain Since 1918 (Oxford, 1963)

Calder, Angus, The People's War: Britain, 1939-1945 (London, 1969)

Campbell, John, 'The Renewal of Liberalism: Liberalism without Liberals', in Gillian Peele and Chris Cook (eds), The Politics of Reappraisal, 1918-1939 (London, 1975), 88-113

Cannadine, David, The Decline and Fall of the British Aristocracy (London, 1990)

Class in Britain (London, 2000)

Carey, John, The Intellectuals and the Masses: Pride and Prejudice among the Literary Intelligentsia, 1880-1939 (London, 1992)

Carroll, Berenice A, 'Feminism and Pacifism: Historical and Theoretical Connections', in Ruth Roach Pierson (ed.), Women and Peace: Theoretical, Historical and Practical Perspectives (London, 1987), 2-28

Ceadel, Martin, Pacifism in Britain, 1914-1945: The Defining of a Faith (Oxford, 1980)

— 'The First British Referendum: The Peace Ballot, 1934-5', English Historical Review, 95 (1980), 810-839

Thinking About Peace and War (Oxford, 1989)

— 'The First Communist "Peace Society": The British Anti-War Movement, 1932-1935', Twentieth Century British History, 1:1 (1990), 58-86

— 'The Peace Movement Between the Wars: Problems of Definition', in Richard 
Taylor and Nigel Young (eds), Campaigns for Peace: British Peace Movements in the Twentieth Century (Manchester, 1997) 73-99

- Semi-Detached Idealists: The British Peace Movement and International Relations, 1854-1945 (Oxford, 2000)

'Gladstone and a Liberal Theory of International Relations', in Peter Ghosh and Lawrence Goldman (eds), Politics and Culture in Victorian Britain: Essays in Memory of Colin Matthew (Oxford, 2006), 74-94

'Cobden and Peace', in Anthony Howe and Simon Morgan (eds), Rethinking Nineteenth-Century Liberalism: Richard Cobden Bicentenary Essays (Aldershot, 2006), 189-207

- 'Gilbert Murray and International Politics', in Christopher Stray (ed.), Gilbert Murray Reassessed: Hellenism, Theatre, and International Politics (Oxford, 2007), 217-237

Cecil, Hugh, Lord Robert Cecil: A Nineteenth-Century Upbringing', History Today, 75 (February 1975), 118-127.

Colley, Linda, Britons: Forging the Nation, 1707-1837 (London, 1992)

Collins, Marcus, Modern Love (London, 2003)

Constantine, Stephan, Buy and Build: The Advertising Posters of the Empire Marketing Board (HMSO, 1986)

Corthorn, Paul, 'The Labour Party and the League of Nations: The Socialist League's Role in the Sanctions Crisis of 1935', Twentieth Century British History, 13:1 (2002), 62-85

Costin, Lela B, 'Feminism, Pacifism, Internationalism and the 1915 International Congress of Women', Women's Studies International Forum, 5 (1982), 301316

Cowling, Maurice, The Impact of Labour 1920-1924: The Beginning of Modern British Politics (Cambridge, 1971)

The Impact of Hitler: British Politics and British Policy, 1933-1940 (Cambridge, 1975)

Crowson, NJ, Facing Fascism: The Conservative Party and the European Dictators, 1935-1940 (London, 1997)

Daunton, Martin and Rieger, Bernhard (eds), Meanings of Modernity: Britain from the Late-Victorian Era to World War II (Oxford, 2001)

Davies, Andrew, Leisure, Gender and Poverty: Working-Class Culture in Salford and Manchester, 1900-1939 (Buckingham, 1992)

Davies, Thomas, The Possibilities of Transnational Activism: The Campaign for Disarmament between the Two World Wars (Leiden, 2008)

Dawson, Michael, 'Liberalism in Devon and Cornwall, 1910-1931: The Old-Time Religion', Historical Journal, 38 (1995), 425-437

Dockrill, Michael, 'The Foreign Office and the "Proposed Institute of International Affairs 1919"', in Andrea Bosco and Cornelia Navari (eds), Chatham House and British Foreign Policy 1919-1945: The Royal Institute of International Affairs during the Interwar Period (London, 1994), 74-86

Doyle, Barry, 'Urban Liberalism and the "Lost Generation": Politics and MiddleClass Culture in Norwich, 1900-1935', Historical Journal, 38 (1995), 617-634 
Dyson, Anthony, 'The Christian Religion', in Terence Thomas (ed.), The British: Their Religious Beliefs and Practices, 1800-1986 (London, 1988), 103-132

Edgerton, David, Warfare State: Britain, 1920-1970 (Cambridge, 2006)

Egerton, George W, Great Britain and the Creation of the League of Nations: Strategy, Politics, and International Organisation, 1914-1919 (Chapel Hill, 1978)

Elliott, BJ, 'The League of Nations Union and History Teaching in England: A Study in Benevolent Bias', History of Education, 6:2 (1977), 131-141

Elshtain, Jean Bethke, 'On Beautiful Souls, Just warriors and Feminist Consciousness', Women's Studies International Forum, 5 (1982), 341-348

English, Jim, 'Empire Day in Britain, 1904-1958', Historical Journal, 49 (2006), 247-276

Fielding, Steven, Class and Ethnicity: Irish Catholics in England, 1880-1939 (Buckingham, 1993)

Fielding, Steven, Thompson, Peter and Tiratsoo, Nick, England Arise! The Labour Party and Popular Politics in 1940s Britain (Manchester, 1995)

Fink, Carole, Defending the Rights of Others: The Great Powers, the Jews, and International Minority Protection, 1878-1938 (Cambridge, 2004)

Fink, Clinton, 'Peace Education and the Peace Movement since 1815', Peace and Change, 6 (1980), 66-73

Formisano, Ronald P, 'The Concept of Political Culture', Journal of Interdisciplinary History, 31 (2001), 393-426

Freeden, Michael, Liberalism Divided: A Study in British Political Thought 1914-1939 (Oxford, 1986)

'Liberal Passions: Reason and Emotion in Late- and Post-Victorian Liberal Thought', in Peter Ghosh and Lawrence Goldman (eds), Politics and Culture in Victorian Britain (Oxford, 2006), 146-149

Freeman, Mark, The Joseph Rowntree Charitable Trust: A Study in Quaker Philanthropy and Adult Education, 1904-1954 (York, 2004)

Fuchs, Eckhart, 'Educational Sciences, Morality and Politics: International Education Congresses in the Early Twentieth Century', Paedagogica Historica, 40 (2004), 757-784

- The Creation of New International Networks in Education: The League of Nations and Educational Organisations in the 1920s', Paedagogica Historica, 43:2 (April 2007), 199-210

Gibberd, Kathleen, Politics on the Blackboard: An Autobiographical Essay (London, 1954)

Giles, Judy, Women, Identity and Private Life in Britain, 1900-1950 (Basingstoke, 1995)

Goodman, Joyce, 'Working for Change Across International Borders: The Association of Headmistresses and Education for International Citizenship', Paedagogica Historica, 43:1 (February 2007), 165-180

Goodwin, Geoffrey, Britain and the United Nations (London, 1957)

Gorman, Daniel, 'Liberal Internationalism, the League of Nations Union, and the Mandates System', Canadian Journal of History, 90 (2005), 449-477

- 'Empire, Internationalism, and the Campaign against the Traffic in Women and Children in the 1920s', Twentieth Century British History, 19 (2008), 186-216

'Ecumenical Internationalism: Willoughby Dickinson, the League of Nations 
and the World Alliance for Promoting International Friendship through the Churches', Journal of Contemporary History, 45 (2010), 51-73

Grant, Kevin, Levine, Philippa and Trentmann, Frank (eds), Beyond Sovereignty: Britain, Empire and Transnationalism, c.1880-1950 (Basingstoke, 2007)

Graves, Pamela, Labour Women: Women in British Working-Class Politics, 1918-1939 (Cambridge, 1994)

Graves, Robert and Hodge, Alan, The Long Weekend: The Exciting Story of the Twenties and Thirties (London, 1940)

Grayson, Richard, Austen Chamberlain and the Commitment to Europe: British Foreign Policy, 1924-29 (London, 1997)

- Liberals, International Relations and Appeasement: The Liberal Party, 1919-1939 (London, 2001)

Green, EHH and Tanner, DM (eds), The Strange Survival of Liberal England: Political Leaders, Moral Values and the Reception of Economic Debate (Cambridge, 2007)

Greenfield, Jill, O'Connell, Sean and Reid, Chris, 'Gender, Consumer Culture and the Middle-Class Male, 1918-1939', in Alan Kidd and David Nicholls (eds), Gender, Civic Culture and Consumerism: Middle-Class Identity in Britain, 18001940 (Manchester, 1999), 183-197

Gregory, Adrian, The Silence of Memory: Armistice Day 1919-1946 (Oxford, 1994)

Griffiths, Richard, Fellow Travellers of the Right: British Enthusiasts for Nazi Germany, 1933-1939 (London, 1980)

Grimley, Matthew, Citizenship, Community, and the Church of England: Liberal Anglican Theories of the State between the Wars (Oxford, 2004)

— 'The Religion of Englishness: Puritanism, Providentialism, and "National Character”, 1918-1945', Journal of British Studies, 46 (2007), 884-906.

Gunn, Simon, The Public Culture of the Victorian Middle Class (Manchester, 2000)

Gupta, Partha Sarathi, Imperialism and the British Labour Movement, 1914-1964 (Basingstoke, 2002, 1st ed. 1975)

Haase, Christian (ed.), Debating Foreign Affairs: The Public and British Foreign Policy since 1867 (Berlin, 2003)

Hall, Catherine and Rose, Sonya (eds), At Home with the Empire: Metropolitan Culture and the Imperial World (Cambridge, 2006)

Halsey, AH with Webb, Josephine (eds), Twentieth-Century British Social Trends (Basingstoke, 2000)

Hamer, DA, The Politics of Electoral Pressure: A Study in the History of Victorian Reform Agitations (Hassocks, 1977)

Hammerton, James, 'The English Weakness? Gender, Satire and "Moral Manliness" in the Lower Middle Class, 1870-1920', in Alan Kidd and David Nicholls (eds), Gender, Civic Culture and Consumerism: Middle-Class Identity in Britain 1800-1940 (Manchester, 1999) 164-182

Hampton, Mark, Visions of the Press in Britain 1850-1950 (Urbana, 2005)

Harris, Jose, William Beveridge: A Biography (Oxford, 1977)

— Private Lives, Public Spirit: Britain, 1870-1914 (London, 1994)

Harrison, Brian, Peaceable Kingdom: Stability and Change in Modern Britain (Oxford, 1982) 
- 'Women in a Men's House: The Women MPs, 1919-1945', Historical Journal, 29 (1986), 623-654

— Prudent Revolutionaries: Portraits of British Feminists Between the Wars (Oxford, 1987)

The Transformation of British Politics, 1860-1995 (Oxford, 1996)

Hastings, Adrian, A History of English Christianity, 1920-2000 (London, 2001)

Hayes, Paul, 'British Foreign Policy, 1867-1900: Continuity and Conflict', in TR Gourvish and Alan O'Day (eds), Later Victorian Britain, 1867-1900 (Basingstoke, 1988), 151-173

Heathorn, Stephen, 'The Mnemonic Turn in the Cultural Historiography of Britain's Great War', Historical Journal, 48 (2005), 1103-1124

Hilton, Matthew, Consumerism in 20th-Century Britain (Cambridge, 2003)

Hinton, James, Protests and Visions: Peace Politics in 20th Century Britain (London, 1989)

Women, Social Leadership, and the Second World War: Continuities of Class (Oxford, 2002)

Hoggart, Richard, The Uses of Literacy (London, 1957)

Hollingworth, Clare, Front Line (London, 1990)

Howe, Stephen, Anticolonialism in British Politics: The Left and the End of Empire, 1918-1964 (Oxford, 1993)

— 'Labour and International Affairs', in Duncan Tanner, Pat Thane and Nick Tiratsoo, Labour's First Century (Cambridge, 2000), 119-150

Hudson, Darril, The Ecumenical Movement in World Affairs (London, 1969)

Hunter, Fred, 'Hilda Matheson and the BBC, 1926-1940', in Sybil Oldfield (ed.), This Working-Day World: Women's Lives and Culture(s) in Britain 1914-1945 (London, 1994), 169-174

Inglehart, Ronald, Modernization and Postmodernization: Cultural, Economic, and Political Change in 43 Societies (Princeton, 1997)

Iriye, Akira, Cultural Internationalism and World Order (London, 1997)

Jalland, Patricia, Women, Marriage and Politics, 1860-1914 (Oxford, 1988)

Jefferys, Kevin, Politics and the People: A History of British Democracy since 1918 (London, 2007)

Jensen, Erik and Fisher, Thomas (eds), The United Kingdom - The United Nations (Basingstoke, 1990)

Jones, Goronwy, Wales and the Quest for Peace (Cardiff, 1969)

Joyce, Patrick, Work, Society and Politics (Hassocks, 1980)

Jupp, James, The Radical Left in Britain, 1931-1941 (London, 1982)

Kamester, Margaret and Vellacott, Jo (eds), Militarism Versus Feminism: Writings on Women and War (London, 1987)

Keenleyside, TA, 'The Indian Nationalist Movement and the League of Nations: Prologue to the United Nations', India Quarterly, 39:3 (1983), 281-298

Kelly, Thomas, A History of Adult Education in Great Britain (Liverpool, 3rd ed., 1992)

Kennedy, Michael, Ireland and the League of Nations, 1919-1946: International Relations, Diplomacy and Politics (Blackrock, 1996) 
Kent, John, William Temple: Church, State and Society in Britain, 1880-1950 (Cambridge, 1992)

Kolasa, Jan, International Intellectual Co-operation: The League Experience and the Beginnings of UNESCO (Wroclaw, 1962)

Koss, Stephen, 'Lloyd George and Nonconformity: The Last Rally', English Historical Review; 89 (1974), 77-108

Koven, Seth and Michel, Sonya (eds), Mothers of the New World: Maternalist Politics and the Origins of Welfare States (London, 1993)

Kuehl, Warren F and Dunn, Lynne K, Keeping the Covenant: American Internationalists and the League of Nations, 1920-1939 (London, 1997)

Kushner, Tony and Valman, Nadia (eds), Remembering Cable Street: Fascism and AntiFascism in British Society (London, 2000)

Kyba, Patrick, Covenants without the Sword: Public Opinion and British Defense Policy 1931-1935 (Waterloo, 1983)

Laity, Paul, The British Peace Movement 1870-1914 (Oxford, 2001)

Langhamer, Claire, Women's Leisure in England, 1920-1960 (Manchester, 2000)

Lauren, Paul Gordon, Craig, Gordon A and George, Alexander L (eds), Force and Statecraft: Diplomatic Challenges of Our Time (Oxford, 2007, 4th ed, first published 1983)

Lavin, Deborah, 'Lionel Curtis and the Founding of Chatham House', in Andrea Bosco and Cornelia Navari (eds), Chatham House and British Foreign Policy 19191945: The Royal Institute of International Affairs during the Interwar Period (London, 1994), 61-71

Lawrence, Jon, Speaking for the People: Party, Language and Popular Politics in England, 1867-1914 (Cambridge, 1998)

— 'Review Article: The British Sense of Class', Journal of Contemporary History, 35:2 (2000), 307-318

'Political History', in Stefan Berger, Heiko Feldner and Kevin Passmore (eds), Writing History: Theory and Practice (London, 2003), 183-202

_ 'Forging a Peaceable Kingdom: War, Violence, and Fear of Brutalisation in Post-First World War Britain', Journal of Modern History, 75 (2003), 557-589

'The Transformation of British Public Politics after the First World War', Past and Present, 190 (2006), 185-216

Lawrence, Jon and Taylor, Miles, 'Introduction: Electoral Sociology and the Historians', in Lawrence and Taylor (eds), Party, State and Society: Electoral Behaviour in Britain since 1820 (Aldershot, 1997), 1-26

Lee, JM, Social Leaders and Public Persons: A Study of County Government in Cheshire since 1888 (Oxford, 1963)

LeMahieu, DL, A Culture for Democracy: Mass Communication and the Cultivated Mind in Britain between the Wars (Oxford, 1988)

Levene, Mark, War, Jews, and the New Europe: The Diplomacy of Lucien Wolf, 19141919 (Oxford, 1992)

Leventhal, FM, The Last Dissenter: HN Brailsford and His World (Oxford, 1985)

Lewis, Jane, Women and Social Action in Victorian and Edwardian England (Aldershot, 1991) 
Liddington, Jill, The Road to Greenham Common: Feminism and Anti-Militarism in Britain since 1820 (London, 1989)

Light, Alison, Forever England: Femininity, Literature and Conservatism between the Wars (London, 1991)

Logan, Anne, 'Professionalism and the Impact of England's First Women Justices, 1920-1950', Historical Journal, 49 (2006), 833-850

Long, David, 'Who Killed the International Studies Conference?', Review of International Studies, 32 (2006), 603-622

Long, David and Wilson, Peter (eds), Thinkers of the Twenty Years' Crisis: Inter-war Idealism Reassessed (Oxford, 1995)

Louis, Wm Roger, In the Name of God, Go! Leo Amery and the British Empire in the Age of Churchill (London, 1992)

Lowe, Rodney, The Welfare State in Britain since 1945 (Basingstoke, 1999)

Lynch, Cecilia, Beyond Appeasement: Interpreting Interwar Peace Movements in World Politics (London, 1999)

McCallum, RB and Readman, Alison, The British General Election of 1945 (Basingstoke, 1999)

McCarthy, Helen, 'Parties, Voluntary Societies and Democratic Politics in Interwar Britain', Historical Journal, 50 (2007), 891-912

_ 'Service Clubs, Citizenship and Equality: Gender Relations and Middle-Class Associations in Britain between the Wars', Historical Research, 81:213 (2008), 531-552

'Petticoat Diplomacy: The Admission of Women to the British Foreign Service, c.1919-1946', Twentieth Century British History, 20 (2009), 285-321

— 'Democratizing Foreign Policy: Rethinking the Peace Ballot, 1934-5', Journal of British Studies, 49 (2010), 358-387

'The League of Nations, Public Ritual and National Identity in Britain, c.19191956', History Workshop Journal, 70 (2010), 108-132

McKibbin, Ross, The Ideologies of Class: Social Relations in Britain 1880-1950 (Oxford, 1990)

- Classes and Cultures: England 1918-1951 (Oxford, 1998)

MacIntyre, Stuart, 'British Labour, Marxism and Working-Class Apathy in the Nineteen Twenties', Historical Journal, 20 (1977), 479-496

MacKenzie, John (ed.), Imperialism and Popular Culture (Manchester, 1986)

— Popular Imperialism and the Military, 1850-1950 (Manchester, 1992)

'The Popular Culture of Empire in Britain', in Judith M Brown and Wm Roger Louis (eds), The Oxford History of the British Empire, Vol.IV: The Twentieth Century (Oxford, 1999), 212-231

Mandler, Peter, The English National Character: The History of an Idea from Edmund Burke to Tony Blair (London, 2006)

Mangan, JA and Walvin, James (eds), Manliness and Morality: Middle-Class Masculinity in Britain and America 1800-1940 (Manchester, 1987)

Marwick, Arthur, 'Middle Opinion in the Thirties: Planning, Progress and Political "Agreement", English Historical Review, 79 (1964), 285-298

Mates, Lewis, The Spanish Civil War and the British Left (London, 2007) 
Matthew, HCG, 'Rhetoric and Politics in Britain, 1860-1950', in PJ Waller (ed.), Politics and Social Change in Britain: Essays Presented to AF Thompson (Brighton, 1987), 34-58

Mayne, Richard and Pindar, John with de V Roberts, John C, Federal Union: The Pioneers (Basingstoke, 1990)

Mazower, Mark, 'Minorities and the League of Nations in Inter-war Europe', Daedelus, 126 (1997), 47-61

—Dark Continent: Europe's Twentieth Century (London, 1998)

Metzger, Barbara, 'Towards an International Human Rights Regime during the Interwar Years: The League of Nations' Combat of Traffic in Women and Children', in Kevin Grant, Philippa Levine and Frank Trentmann (eds), Beyond Sovereignty: Britain, Empire and Transnationalism, c.1880-1950 (Basingstoke, 2007), 54-79

Mews, Stuart, 'Religion, 1900-1939', in Chris Wrigley (ed.), A Companion to Early Twentieth-Century Britain (Oxford, 2003), 470-484

Middlemas, Keith, Politics in Industrial Society: The Experience of the British System since 1911 (London, 1979)

Middlemas, Keith and Barnes, John, Baldwin: A Biography (London, 1969)

Miller, Carol, "Geneva - the Key to Equality": Inter-war Feminists and the League of Nations', Women's History Review, 3 (1994), 219-245

Morefield, Jeanne, Covenants without Swords: Idealist Liberalism and the Spirit of Empire (Princeton, 2005)

Morgan, Kenneth O, Consensus and Disunity: The Lloyd George Coalition Government 1918-1922 (Oxford, 1979)

- Modern Wales: Politics, Places and People (Cardiff, 1995)

Mowat, CL, Britain Between the Wars, 1918-1940 (London, 1966, 1st ed 1955)

Nicolson, Nigel (ed.), The Harold Nicolson Diaries 1907-1964 (London, 2005)

Norman, ER, Church and Society in England, 1770-1970: A Historical Study (Oxford, 1976)

Northedge, FS, The Troubled Giant: Britain Among the Great Powers 1916-1939 (London, 1966)

The League of Nations: Its Life and Times, 1920-1946 (Leicester, 1986)

'The Department of International Relations at LSE: A Brief History, 19241971', in Henry Bauer and Elisabetta Brighi (eds), International Relations at LSE: A History of 75 Years (London, 2003), 7-27

Obelkevich, James, 'Religion', in FML Thompson (ed.), The Cambridge Social History of Britain, 1750-1950, Vol.III (Cambridge, 1990), 311-356

Omissi, David Enrico, 'The Hendon Air Pageant, 1920-1937', in John MacKenzie (ed.), Popular Imperialism and the Military, 1850-1950 (Manchester, 1986) 198119

Overy, Richard, The Morbid Age: Britain between the Wars (London, 2009)

Owen, Nicholas, 'Critics of Empire in Britain', in Judith M Brown and Wm Roger Louis (eds), The Oxford History of the British Empire, Vol.IV: The Twentieth Century (Oxford, 1999), 188-211

— 'MacDonald's Parties: The Labour Party and the "Aristocratic Embrace", 19221931', Twentieth Century British History, 18:1 (2007), 1-53. 
Parkin, Frank, Middle-Class Radicalism: The Social Bases of the British Campaign for Nuclear Disarmament (Manchester, 1968)

Parmar, Inderjeet, 'Anglo-American Elites in the Interwar Years: Idealism and Power in the Intellectual Roots of Chatham House and the Council on Foreign Relations', International Relations, 16:53 (2002), 53-75

Pedersen, Susan, Eleanor Rathbone and the Politics of Conscience (London, 2004)

_ 'Back to the League of Nations', American Historical Review, 112:4 (2007), 1091-1117

_ 'Metaphors of the Schoolroom: Women Working the Mandates System of the League of Nations', History Workshop Journal, 66 (2008), 188-207

Pedersen, Susan and Mandler, Peter (eds), After the Victorians: Private Conscience and Public Duty in Modern Britain (London, 1994)

Perkin, Harold, The Rise of Professional Society: England since 1880 (London, 1989)

Perry, Matt, The Jarrow Crusade: Protest and Legend (Sunderland, 2005)

Pienaar, Sara, South Africa and International Relations between the Two World Wars: The League of Nations Dimension (Johannesburg, 1987)

Porter, Bernard, The Absent-Minded Imperialists: Empire, Society, and Culture in Britain (Oxford, 2004)

Porter, Brian (ed.), The Aberystwyth Papers: International Politics 1919-1969 (London, 1972)

Potts, Archie, Zilliacus: A Life for Peace and Socialism (London, 2002)

Pugh, Martin, The Tories and the People 1880-1935 (Oxford, 1985)

- State and Society: British Political and Social History 1870-1992 (London, 1994)

-Women and the Women's Movement in Britain, 1914-1999 (Basingstoke, 2000, 2nd ed.)

Pugh, Michael, 'Pacifism and Politics in Britain, 1931-1935', Historical Journal, 23:3 (1980), 641-656

Ramsden, John, The Age of Balfour and Baldwin, 1902-1940 (London, 1978)

Renna, Thomas, 'Peace Education: An Historical Overview', Peace and Change, 6 (1980), 61-65

Reynolds, PA, British Foreign Policy in the Inter-War Years (London, 1954)

Rich, Paul, 'Alfred Zimmern's Cautious Idealism: The League of Nations, International Education, and the Commonwealth', in David Long and Peter Wilson (eds), Thinkers of the Twenty Years' Crisis: Inter-war Idealism Reassessed (Oxford, 1995), 79-99

Rigby, Andrew, 'The Peace Pledge Union: From Peace to War, 1936-1945', in Peter Brock and Thomas P Socknat (eds), Challenge to Mars: Essays on Pacifism from 1918-1945 (London, 1999), 169-185

Ritschel, Daniel, The Politics of Planning: The Debate on Economic Planning in Britain in the 1930s (Oxford, 1997)

Robbins, Keith, Munich 1938 (London, 1968)

- The Abolition of War: The 'Peace Movement' in Britain, 1914-1919 (Cardiff, 1976)

- History, Religion and Identity in Modern Britain (London, 1993)

- England, Ireland, Scotland, Wales: The Christian Church, 1900-2000 (Oxford, 2008) 
Rose, Jonathan, The Intellectual Life of the British Working Classes (London, 2001)

Rose, Kenneth, The Later Cecils (London, 1975)

Rubinstein, WD, 'Wealth, Elites and the Class Structure of Modern Britain', Past and Present, 76 (1977), 99-126

'Britain's Elites in the Interwar Period, 1918-1939', in Alan Kidd and David

Nicholls (eds), The Making of the British Middle Class? Studies of Regional and

Cultural Diversity since the Eighteenth Century (Stroud, 1998), 186-202

Rüger, Jan, The Great Naval Game: Britain and Germany in the Age of Empire (Cambridge, 2007)

Searle, GR, Country Before Party: Coalition and the Idea of 'National Government' in Modern Britain, 1885-1987 (Harlow, 1995)

Sluga, Glenda, The Nation, Psychology, and International Politics, 1870-1919 (Basingstoke, 2006)

Spier, Eugen, Focus: A Footnote to the History of the Thirties (London, 1963)

Springhall, John, Youth, Empire and Society: British Youth Movements, 1883-1940 (London, 1977)

Stacey, Margaret, Tradition and Change: A Study of Banbury (Oxford, 1960)

Stannage, Tom, Baldwin Thwarts the Opposition: The British General Election of 1935 (London, 1980)

Stapleton, Julia, 'The Classicist as Liberal Intellectual: Gilbert Murray and Alfred Eckhart Zimmern', in Christopher Stray (ed.), Gilbert Murray Reassessed: Hellenism, Theatre, and International Politics (Oxford, 2007), 261-291

Stedman Jones, Gareth, 'Rethinking Chartism', in Languages of Class: Studies in English Working Class History 1832-1982 (Cambridge, 1983), 90-178

Stevenson, John and Cook, Chris, Britain in the Depression: Society and Politics 1929-39 (Harlow, 1994, 2nd ed.)

Stocks, Mary, My Commonplace Book (London, 1970)

Studdert-Kennedy, Gerald, Dog-Collar Democracy: The Industrial Christian Fellowship 1919-1929 (London, 1982)

Swartz, Marvin, The Union of Democratic Control in British Politics during the First World War (Oxford, 1971)

Taylor, AJP, The Trouble Makers: Dissent over Foreign Policy 1792-1939 (London, 1957)

- Origins of the Second World War (London, 1963)

English History 1914-1945 (Oxford, 1965)

Taylor, Miles, 'John Bull and the Iconography of Public Opinion in England, c.17121929', Past and Present, 134 (1992), 93-128

Taylor, Philip M, The Projection of Britain: British Overseas Publicity and Propaganda 1919-1939 (Cambridge, 1981)

Taylor, Richard, Against the Bomb: The British Peace Movement 1958-1965 (Oxford, 1988)

Thane, Pat, 'What Difference Did the Vote Make?', in Amanda Vickery (ed.), Women, Privilege and Power: British Politics, 1750 to the Present (Stanford, 2001), 253-288

Thompson, Andrew, Imperial Britain: The Empire in British Politics, c.1880-1932 (Harlow, 2000) 
The Empire Strikes Back? The Impact of Imperialism on Britain from the MidNineteenth Century (Harlow, 2005)

Thompson, James, 'Pictorial Lies?: Posters and Politics in Britain, 1880-1914', Past and Present, 197 (2007), 177-210

Thompson, JA, 'The League of Nations Union and Promotion of the League Idea in Great Britain', Australian Journal of Politics and History, 18 (1972), 52-61

— 'Lord Cecil and the Pacifists in the League of Nations Union', Historical Journal, 20 (1977), 949-959

'The Peace Ballot and the Public', Albion, 13 (1981), 380-392

-The "Peace Ballot" and the "Rainbow" Controversy', Journal of British Studies, 20 (1981), 150-170

'The Peace Ballot of 1935: The Welsh Campaign', Welsh History Review, 11 (1983), 388-399

Thorpe, Andrew, Parties at War: Political Organisation in Second World War Britain (Oxford, 2009)

Towle, Philip, Going to War: British Debates from Wilberforce to Blair (Basingstoke, 2009)

Trainor, Rick, "The "Decline" of British Urban Governance since 1850: A Reassessment', in Rick Trainor and RJ Morris (eds), Urban Governance: Britain and Beyond since 1750 (Aldershot, 2000), 28-46

Trentmann, Frank, Free Trade Nation: Commerce, Consumption and Civil Society in Modern Britain (Oxford, 2008)

Veatch, Richard, Canada and the League of Nations (Toronto, 1975)

Vellacott, Jo, Pacifists, Patriots and the Vote (Basingstoke, 2007)

Wahrman, Dror, Imagining the Middle Class: The Political Representation of Class in Britain, c.1780-1840 (Cambridge, 1995)

Waley, Daniel, British Public Opinion and the Abyssinian War (London, 1975)

Waters, Chris, British Socialists and the Politics of Popular Culture, 1884-1918 (Stanford, 1990)

Watkins, Christopher, 'Inventing International Citizenship: Badminton School and the Progressive Tradition between the Wars', History of Education, 36 (2007), 315-338

Weight, Richard and Beach, Abigail (eds), The Right to Belong: Citizenship and National Identity in Britain, 1930-1960 (London, 1998)

West, Francis, Gilbert Murray: A Life (Beckenham, 1984)

Whitmarsh, Guy, 'The Politics of Political Education: An Episode', Journal of Curriculum Studies, 6 (1974), 133-142

Wilkinson, Alan, Dissent or Conform? War, Peace and the English Churches 1900-1945 (London, 1986)

Williams, Francis, Journey into Adventure: The Story of the Workers Travel Association (London, 1960)

Williamson, Philip, The Labour Party and the House of Lords', Parliamentary History, 10 (1991), 317-341 1999) 
'Christian Conservatives and the Totalitarian Challenge, 1933-1940', English Historical Review, 115 (2000), 607-642

Wilson, Duncan, Gilbert Murray OM, 1866-1957 (Oxford, 1987)

Wilson, Keith, "The Foreign Office and the "Education" of Public Opinion before the First World War', Historical Journal, 26:2 (1983), 403-411

Wilson, Peter, 'Retrieving Cosmos: Gilbert Murray's Thought on International Relations', in Christopher Stray (ed.), Gilbert Murray Reassessed: Hellenism, Theatre, and International Politics (Oxford, 2007), 239-260

Windscheffel, Alex, Popular Conservatism in Imperial London 1868-1906 (Woodbridge, 2007)

Wolffe, John, God and Greater Britain: Religion and National Life in Britain and Ireland 1843-1945 (London, 1994)

Wootton, Graham, The Politics of Influence: British Ex-servicemen, Cabinet Decisions and Cultural Change, 1917-1957 (London, 1963)

Wybrow, Robert J, Britain Speaks Out, 1937-1987: A Social History as Seen Through the Gallup Data (Basingstoke, 1989)

Yearwood, Peter, Guarantee of Peace: The League of Nations in British Policy, 1914-1925 (Oxford, 2009)

\section{Unpublished secondary material}

Barty, Peter Frederick, 'The League of Nations Union Between the Wars: The Rise and Decline of a British Political Pressure Group' (PhD thesis, University of Kentucky, 1964)

Bridgen, Paul, 'Ideology and Politics in the Development of a Labour Party Foreign Policy 1900-1924' (PhD thesis, Goldsmith's College, 2001)

Miller, Carol, 'Lobbying the League: Women's International Organisations and the League of Nations' (DPhil thesis, University of Oxford, 1992) 